\title{
Density, body size and sex ratio of an indigenous spider along an altitudinal gradient in the sub-Antarctic
}

\author{
JENNIFER E. LEE ${ }^{\mathbf{1}}$, MICHAEL J. SOMERS ${ }^{\mathbf{2}, \mathbf{3}}$ and STEVEN L. CHOWN ${ }^{\mathbf{1}}$ \\ ${ }^{1}$ Centre for Invasion Biology, Department of Botany and Zoology, Stellenbosch University, Private Bag X1, Matieland 7602, \\ South Africa \\ ${ }^{2}$ Centre for Wildlife Management, Centre for Invasion Biology, University of Pretoria, Pretoria 0002, South Africa \\ ${ }^{3}$ Department of Zoology, Walter Sisulu University, Private Bag X1, UNITRA 5117, South Africa \\ jlee@sun.ac.za
}

\begin{abstract}
Although spiders are a diverse and ecologically important group of predators across the sub-Antarctic islands, relatively little is known about their biology. Here we provide data on the abundance, body size variation and sex ratio of an indigenous spider, Myro kerguelenensis, across an altitudinal gradient on Marion Island. In so doing we test explicitly the hypotheses that density will decline with declining resource availability at higher elevations, and that a converse Bergmann body size cline will be found in this species. Density of $M$. kerguelenensis decreased with altitude and ranged from a mean density of 5.3 (SD 3.42) individuals per $\mathrm{m}^{2}$ at $50 \mathrm{~m}$ a.s.1. to a mean density of 0.83 (SD 1.15) individuals per $\mathrm{m}^{2}$ at $600 \mathrm{~m}$ a.s.l. Mean female sternum width was $1.39 \mathrm{~mm}$ (SD 0.44) and mean male sternum width was $1.40 \mathrm{~mm}$ (SD 0.22). No evidence for Bergmann or converse Bergmann clines was found. At increasing altitudes, sex ratios became increasingly female-biased with populations at $600 \mathrm{~m}$ a.s.l. comprising 0.87 (SD 0.28) females, on a proportional basis, possibly as a result of resource limitation and an increase in the prevalence of sexual cannibalism. The food web implications of this study are highlighted.
\end{abstract}

Received 14 February 2011, accepted 14 June 2011, first published online 23 September 2011

Key words: Araneae, Bergman body size cline, Marion Island, Myro kerguelenensis, resource limitation

\section{Introduction}

Understanding the relative importance of the biotic and abiotic factors affecting species abundances forms a key component of comprehending the distribution of biodiversity and how this may change in the future. In high latitude and high altitude environments, abiotic factors take primacy in controlling the abundance and distribution of biota (Convey et al. 2006, Hogg et al. 2006). Abiotic factors are especially significant in continental Antarctica where just a few environmental parameters can explain high proportions of the variation in biodiversity (Chown \& Convey 2007). However, in the lower latitude sub-Antarctic, ecosystems become more complex and, although abiotic factors may still be important in determining the abundances and distributions of some species (le Roux \& McGeoch 2008a, Lee et al. 2009), biotic interactions are expected to play an increasingly important role in structuring communities (Chown 1992, Convey et al. 2006, le Roux \& McGeoch 2008a).

The significance of predation has been highlighted by the impacts of introduced mammals such as rodents and cats that have profound impacts on other taxa (see Frenot et al. 2005 for review). Introduced invertebrates are also important, functioning both as predators and parasitoids, with a range of impacts at the population and community levels (Chown \& Block 1997, Ernsting et al. 1999, Lee et al. 2007). However, the role of indigenous predators and parasitoids, and indeed of biotic interactions generally, in affecting populations and ecosystems, is usually considered relatively unimportant in sub-Antarctic and other Antarctic terrestrial ecosystems (Hogg et al. 2006), largely because of the paucity of such species. Nonetheless, indigenous predators and parasitoids are found in the sub-Antarctic, and predators can be found among the mites and beetles (e.g. Davies 1972, Arnold \& Convey 1998, Hogg et al. 2006), and importantly in the form of spiders, which are common across the region.

Approximately 126 species of spiders have been recorded across the Southern Ocean islands (Pugh 2004), but despite their species richness relatively little is known about their biology. Elsewhere, spiders are important predators of soil microfauna such as springtails, which can in turn affect litter decomposition and nutrient availability (Lawrence \& Wise 2000). In sub-Antarctic environments, the cool, wet, oceanic climate restricts microbial and chemical decomposition; soil-dwelling invertebrates play an important role in nutrient cycling (Smith 2008). Therefore, knowledge of the distribution and abundance of important predators of invertebrates, such as the spiders, is important for understanding potential impacts on nutrient cycles and primary productivity (Smith 2008). However, for the majority of spider species in the region, information about their local distributions, life histories and prey preferences remains largely unavailable. Specific species are often not identified in surveys of invertebrate distributions and abundances (e.g. Burger 1978, though see 
also Khoza et al. 2005), and only limited data exist on the life histories and physiological characteristics of species in the region (e.g. Ysnel \& Ledoux 1988, Jumbam et al. 2008). In consequence, little is known about how important spiders, and indeed many other predators, may be in food webs on the sub-Antarctic islands, which may also partly account for the fact that predation is not regarded an important process in the region (see Convey et al. 2006, Hogg et al. 2006 for additional discussion). Rectifying this situation is important if biotic interactions between predator and prey species in the sub-Antarctic, which remain poorly investigated (but see Smith 2008), are to be more comprehensively understood.

Here we provide the first estimate of the density and body size variation of Myro kerguelenensis Desidae, one of two indigenous spider species found on sub-Antarctic Marion Island (Khoza et al. 2005) across an altitudinal gradient from 50 to $600 \mathrm{~m}$ a.s.l. We do so following Andrewartha \& Birch's (1954) rationale that to understand the demography of any population, the environment, physiology and behaviour of the organism, and density variation thereof need to be investigated. Previous studies provide some of the physiological and environmental background (see Jumbam et al. 2008 and Chown \& Froneman 2008 for review), whereas spatially explicit information on densities is not available at the species level for spiders either on this island or throughout the region. Across this gradient there is a substantial decrease in vegetation cover (Smith et al. 2001) and the abundance of

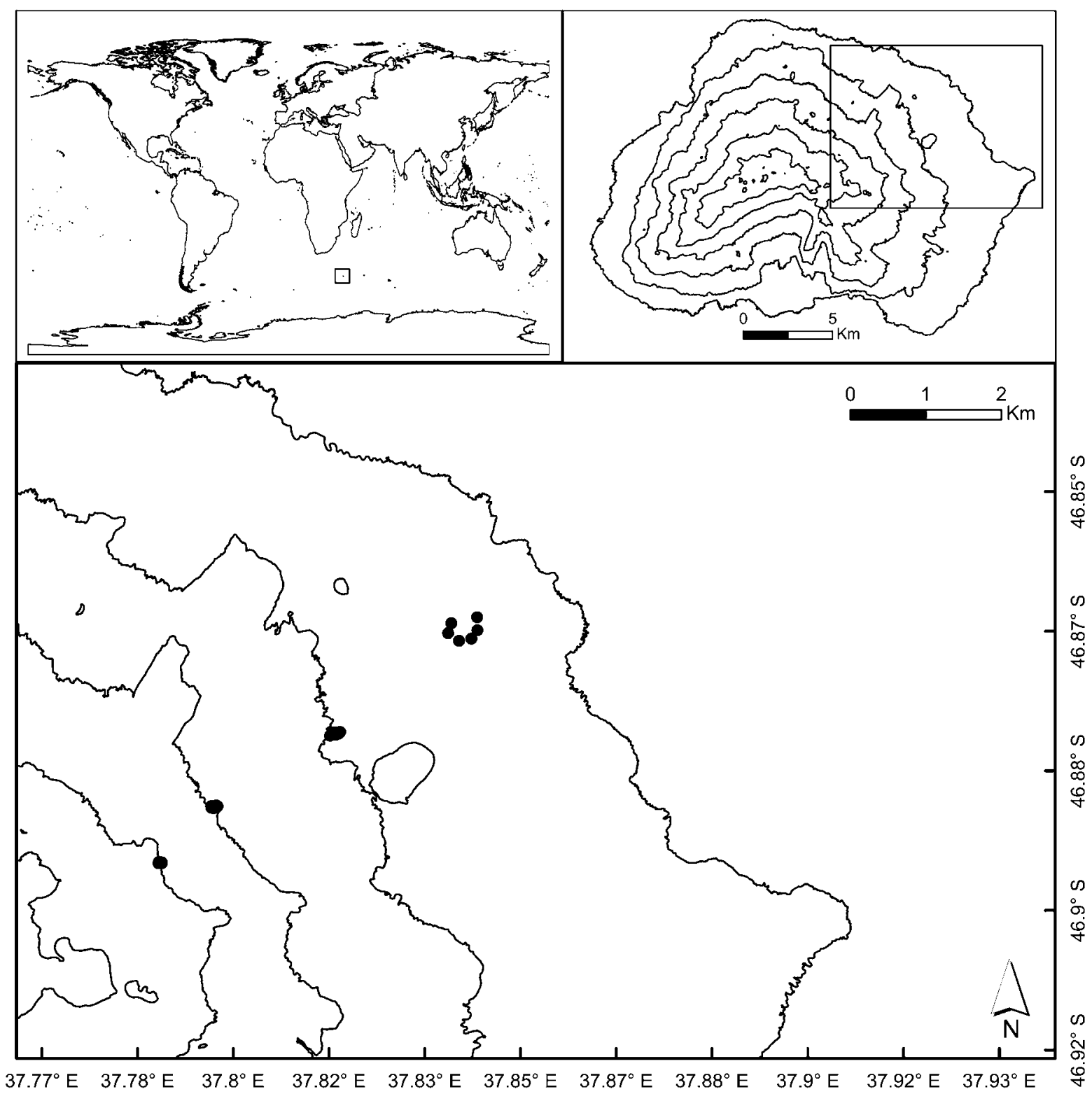

Fig. 1. Black circles represent sampling sites at 50, 200, 400 and $600 \mathrm{~m}$ a.s.1. on Marion Island. Contours are at $200 \mathrm{~m}$ intervals. Insets show position of Marion Island globally and position of sites relative to the island. 
invertebrates upon which spiders may prey appears to show a similar decline (Barendse \& Chown 2001, Gabriel et al. 2001, Abraham et al. 2011, and Davies \& Melbourne 1999 for an example from Macquarie Island). Therefore, we hypothesize that as a result of resource limitation, spider densities will show a negative relationship with altitude and be highest in the resource rich coastal areas and decline towards the resource poor, high altitude interior of the island.

We include information on size because it is so strongly related to many life history and physiological variables in the arthropods (Peters 1983) and can be used as a proxy for estimating impacts across trophic levels (see Cohen et al. 2003, 2005 for a general framework and Chown \& Smith 1993, Ernsting et al. 1999 for sub-Antarctic examples). Moreover, because we sampled over a substantial elevational range, which in other species on the island is associated with a substantial size increase (c. 20-30\%) associated with little variation in seasonality (Chown \& Klok 2003), we also hypothesize that M. kerguelenensis will show a converse Bergmann size cline (see Blanckenhorn \& Demont 2004, Chown \& Gaston 2010). In Arctic spider species, body size dimorphism has also been shown to be a life history character that is strongly influenced by climate change (Høye et al. 2009). On an island where daily mean, minimum and maximum temperatures on average have increased by almost one degree over the last 50 years and over a similar period annual rainfall has declined by over $1000 \mathrm{~mm}$ (le Roux \& McGeoch 2008b), significant changes in invertebrate populations and community interactions can be expected. These data provide a baseline against which such changes can be measured.

\section{Material and methods}

Fellfield habitats on Marion Island are characterized by nutrient poor, stone covered soils, low plant cover and the dominance of the cushion forming plant Azorella selago Hook. f. (Smith et al. 2001). In fellfield sites at altitudes of $50,200,400$ and $600 \mathrm{~m}$ a.s.l. six sites per altitude were established with each site being more than $50 \mathrm{~m}$ but less than $200 \mathrm{~m}$ away from other sites at the same altitude (Fig. 1). Fellfield habitats were selected for this study because they are the dominant vegetation type below $500 \mathrm{~m}$ a.s.l. on Marion Island, occupying $60 \%$ of the area available to terrestrial communities (Smith et al. 2001). They are also a significant component of the Antarctic region. Surveys were restricted to a maximum altitude of $600 \mathrm{~m}$ a.s.l. because above this altitude, vegetation is sparse and pilot surveys indicated that $M$. kerguelenensis is absent. This observation is supported by Lawrence (1971) who asserted that only M. paucispinosus Berland is found in the polar desert habitat which is dominant above $600 \mathrm{~m}$ a.s.l.

Because of the extremely high rainfall on Marion Island (c. $2000 \mathrm{~mm}$ per year at sea level, with higher totals at higher elevations, le Roux \& McGeoch 2008b, A. Treasure personal communication 2010) pitfall trapping proved to be impractical and we suspected it would introduce considerable bias into the results. Thus, we elected to conduct a visual search for spiders in two haphazardly placed $\left(1 \mathrm{~m}^{2}\right)$ quadrats at each site, during daylight hours (typically between $10 \mathrm{~h} 00$ and 15h00), once per month in January, March, June, July, September and November 2004. All spiders found were returned to the laboratory in individual vials to prevent cannibalism. Data from the two quadrats were not amalgamated. Specimens were sexed and sternum width was measured using a Wild M3 microscope with a calibrated ocular micrometer at $40 \mathrm{x}$ magnification. To allow comparisons with studies which use carapace width as an index of body size (Hagstrum 1971), in April 2011 the carapace and sternum width of 50 individuals of Myro kerguelenensis were measured and the relationship between the two measures compared using ordinary least squares regression. Because of a high coefficient of determination $\left(r^{2}>0.9\right)$, reduced major axis regression would have produced a similar relationship (Quinn \& Keough 2002) and so was not used.

Mean densities were calculated and sex ratios and frequency distributions of male and female body length were plotted. To assess whether there was spatial independence within sites, Moran's I values were calculated for each month at each altitude. Spatial correlograms based on eight equalfrequency classes were used to present graphically the changes in the Moran's I coefficients (Legendre \& Legendre 1998). Overall significance of each correlogram was assessed with progressive Bonferroni correction and used to correct individual distance class I values for multiple comparisons. Spatial non-independence in density across sites was not assessed because it is confounded by altitudinal variation in environmental conditions (le Roux \& McGeoch 2008a), i.e. the east-west gradient in spider density is confounded by changes in altitude.

Generalized linear models were implemented using the glm function in the stats library in $\mathrm{R}$ version 2.12.0 (R Development Core Team 2010). The first model compared spider densities between altitudes and used number of $M$. kerguelenensis per quadrat as the response variable, site and month as categorical predictors, and altitude as a continuous predictor. A second model compared sternum width across altitudes and used sternum width as the response variable, month, site and sex as categorical predictors and altitude as a continuous predictor. For spider density models a Poisson distribution with a log-link function was used and for body length a Gaussian distribution and an identity function was used. Best-fit models were identified using the Akaike Information Criterion (AIC) and Akaike weights (Johnson \& Omland 2004).

\section{Results}

Over the 12-month study period 978 spiders were found of which 943 were Myro kerguelenensis and therefore 


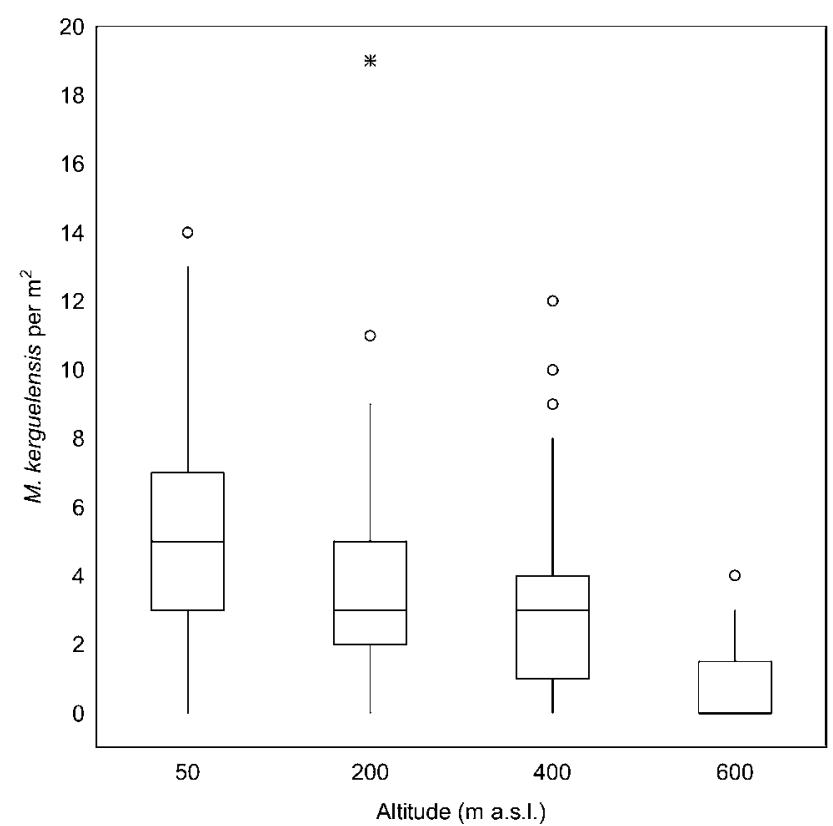

Fig. 2. Boxplot showing median (25-75\%), non-outlier range (whiskers), outliers (o) and extremes $(*)$ of number of M. kerguelenensis found $1 \mathrm{~m}^{-2}$ across the sampled altitudinal gradient.

all further analysis focused on this species. Of the M. kerguelenensis collected, only six were juveniles. Low numbers of juveniles may be an artefact of the collection method and they were therefore excluded from all analyses.

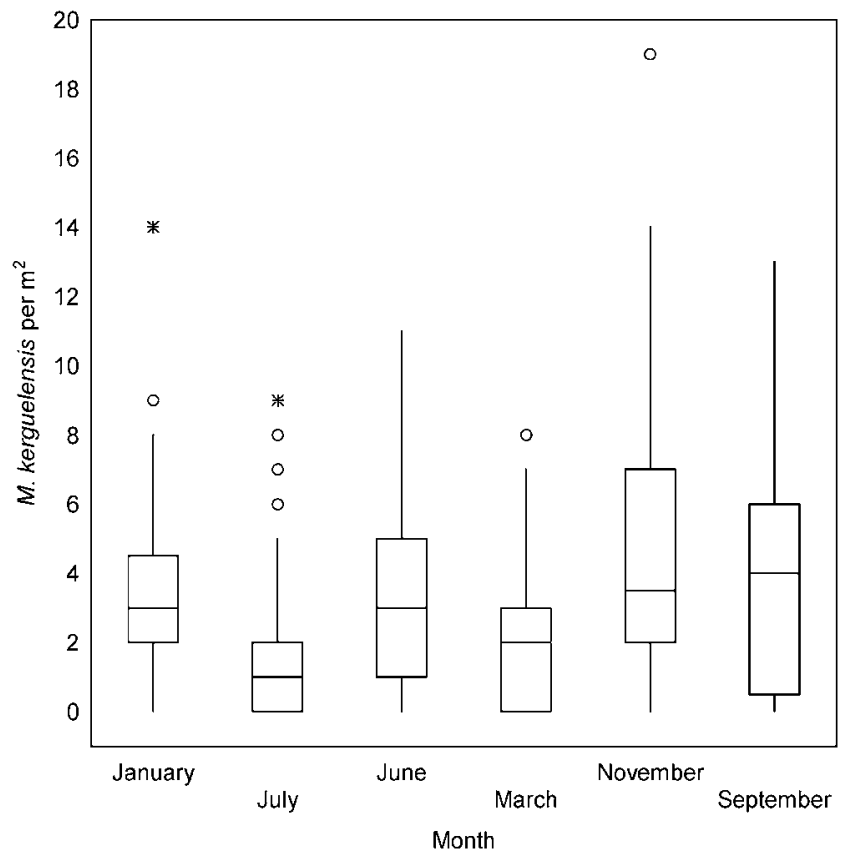

Fig. 3. Boxplot showing median (25-75\%), non-outlier range (whiskers), outliers (o) and extremes $(+)$ of number of M. kerguelenensis found $1 \mathrm{~m}^{-2}$ in different months of the year.
Table I. Outcome of the best-fit Generalized Linear Model (assuming a Poisson distribution and using a log link function) describing the abundance of $M$. kerguelenensis across an altitudinal gradient over a one-year period.

\begin{tabular}{llcccc}
\hline & & Estimate & s.e. & Wald & $P$-value \\
\hline (Intercept) & & 1.837 & 0.082 & 22.341 & $<0.001$ \\
Month & July & -0.735 & 0.134 & -5.472 & $<0.001$ \\
& June & -0.073 & 0.110 & -0.660 & 0.509 \\
& March & -0.488 & 0.124 & -3.934 & $<0.001$ \\
& November & 0.322 & 0.100 & 3.208 & $<0.01$ \\
& September & 0.116 & 0.105 & 1.102 & 0.271 \\
Altitude & & -0.002 & 0.000 & -14.645 & $<0.001$ \\
\hline
\end{tabular}

Density of $M$. kerguelenensis adults decreased with altitude, ranging from a mean density of 5.3 (SD 3.42) individuals per $\mathrm{m}^{2}$ at $50 \mathrm{~m}$ a.s.l. to a mean density of 0.83 (SD 1.15) individuals per $\mathrm{m}^{2}$ at $600 \mathrm{~m}$ a.s.l. (Fig. 2). Densities were highest in summer months (September and November) and lowest in winter (July) (Fig. 3). Moran's I values were only significant for five distance lags in the 22 corelograms (six distance lags per corelogram) (Supplemental Fig. 1). Thus, within sites in this study, negligible spatial structure in spider density was found. In other words, quadrats placed within sites can be considered independent replicates. The best-fit model describing the density of $M$. kerguelenensis across all sites included terms for month and altitude $\left(\mathrm{w}_{\mathrm{i}} 0.628, \mathrm{df}=281\right.$, null deviance $=908.75$, residual deviance $=568.65) \quad($ Table I $)$ (see Supplemental Table 1 for AIC values and weights for all models).

Mean female sternum width was $1.39 \mathrm{~mm}$ (SD 0.44) and mean male sternum width was $1.40 \mathrm{~mm}$ (SD 0.22). Female

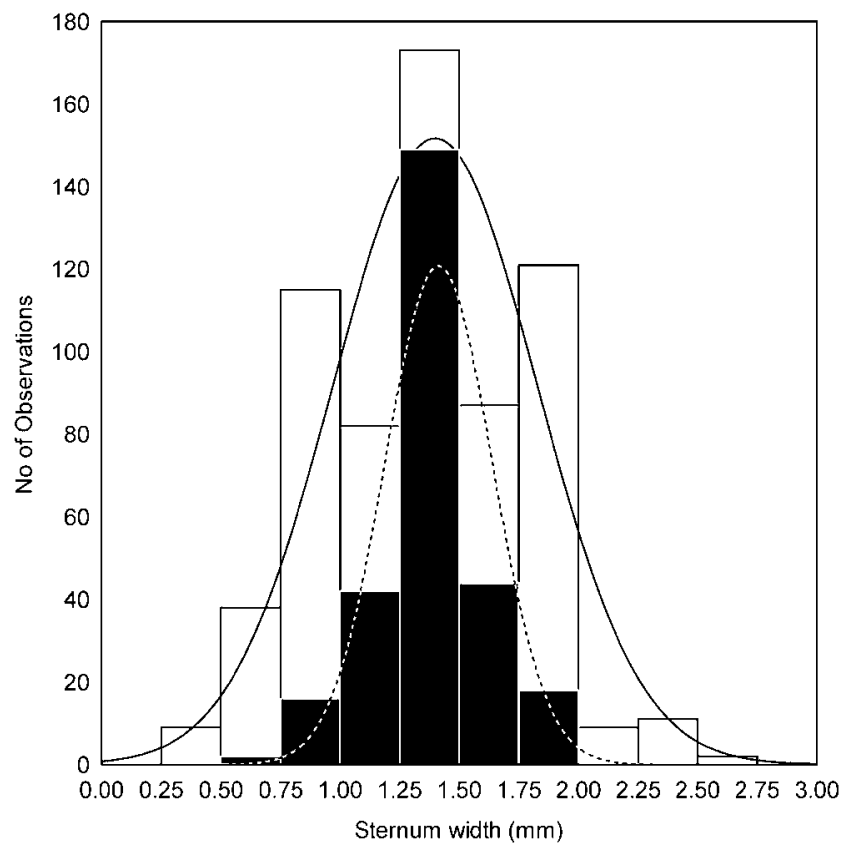

Fig. 4. Frequency distribution of male (black bars) and female (open bars) M. kerguelenensis sternum width. 
Table II. Outcome of the best-fit Generalized Linear Model (assuming a Gaussian distribution and using a identity link function) describing the sternum width of $M$. kerguelenensis across an altitudinal gradient over a one-year period.

\begin{tabular}{llcccc}
\hline & & Estimate & s.e. & Wald & $P$-value \\
\hline (Intercept) & & 1.538 & 0.029 & 51.712 & $<0.001$ \\
Month & July & -0.109 & 0.040 & -2.241 & $<0.05$ \\
& June & 0.125 & 0.039 & 3.162 & $<0.001$ \\
& March & -0.077 & 0.044 & -1.776 & 0.089 \\
& November & -0.263 & 0.036 & -7.336 & $<0.001$ \\
& September & -0.239 & 0.037 & -6.396 & $<0.001$ \\
Altitude & & -0.001 & 0.001 & -2.432 & $<0.05$ \\
\hline
\end{tabular}

sternum width ranged from $0.5-2.7 \mathrm{~mm}$ whilst males sternum width ranged from $0.7-2 \mathrm{~mm}$ (Fig. 4). Ordinary Least Squares regression showed a strong relationship between sternum width and carapace width (carapace width $=-0.080 \pm 0.058$ (s.e.) * sternum width $+1.737 \pm 0.07$ (s.e.), $\quad \mathrm{F}_{(1,48)}=496.24, \quad P<0.001, \quad r^{2}=0.911, \quad$ s.e. $\quad$ of estimate $=0.057)$. The best-fit model describing $M$. kerguelenensis sternum width included terms for month and altitude $\left(\mathrm{w}_{\mathrm{i}}\right.$ 0.46, $\mathrm{df}=938$, null deviance $=130.49$, residual deviance $=110.73$; Table II) (see Supplemental Table 2 for AIC values and weights for all models). Although sampling method may have biased the size and sex of spiders collected, making comparisons with other studies problematic, comparisons among sites at different altitudes on Marion Island remain valid. At low altitude sites, sex ratios were approximately equal. However, at increasing altitudes, sex ratios became increasingly female-biased with populations at $600 \mathrm{~m}$ a.s.l. comprising 0.87 (SD 0.28)

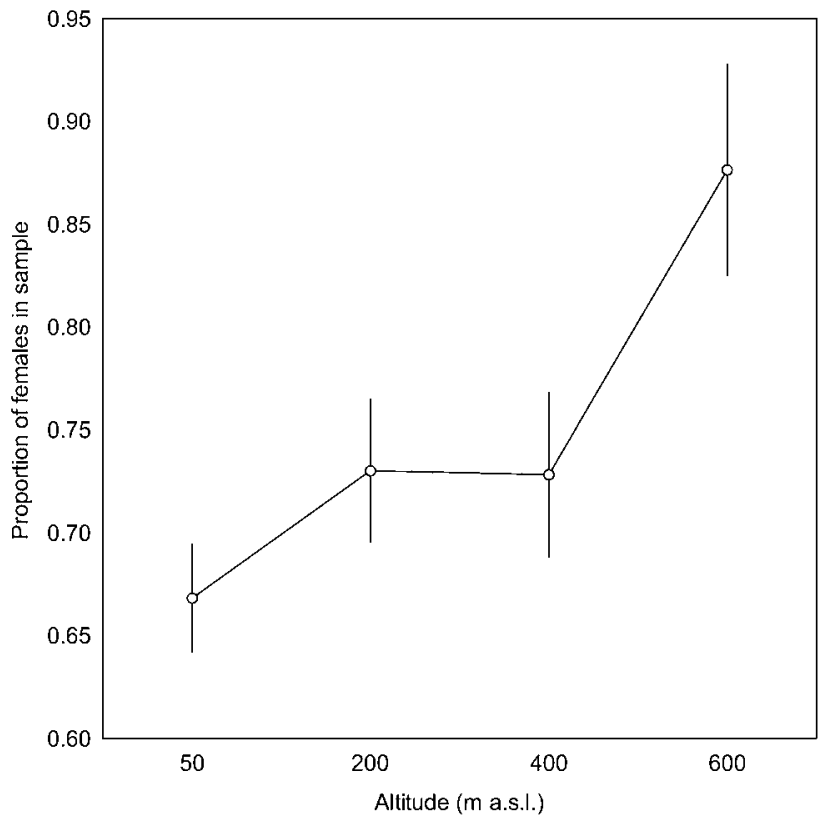

Fig. 5. Mean ( \pm s.e) proportion of females in samples of M. kerguelenensis collected across an altitudinal gradient.

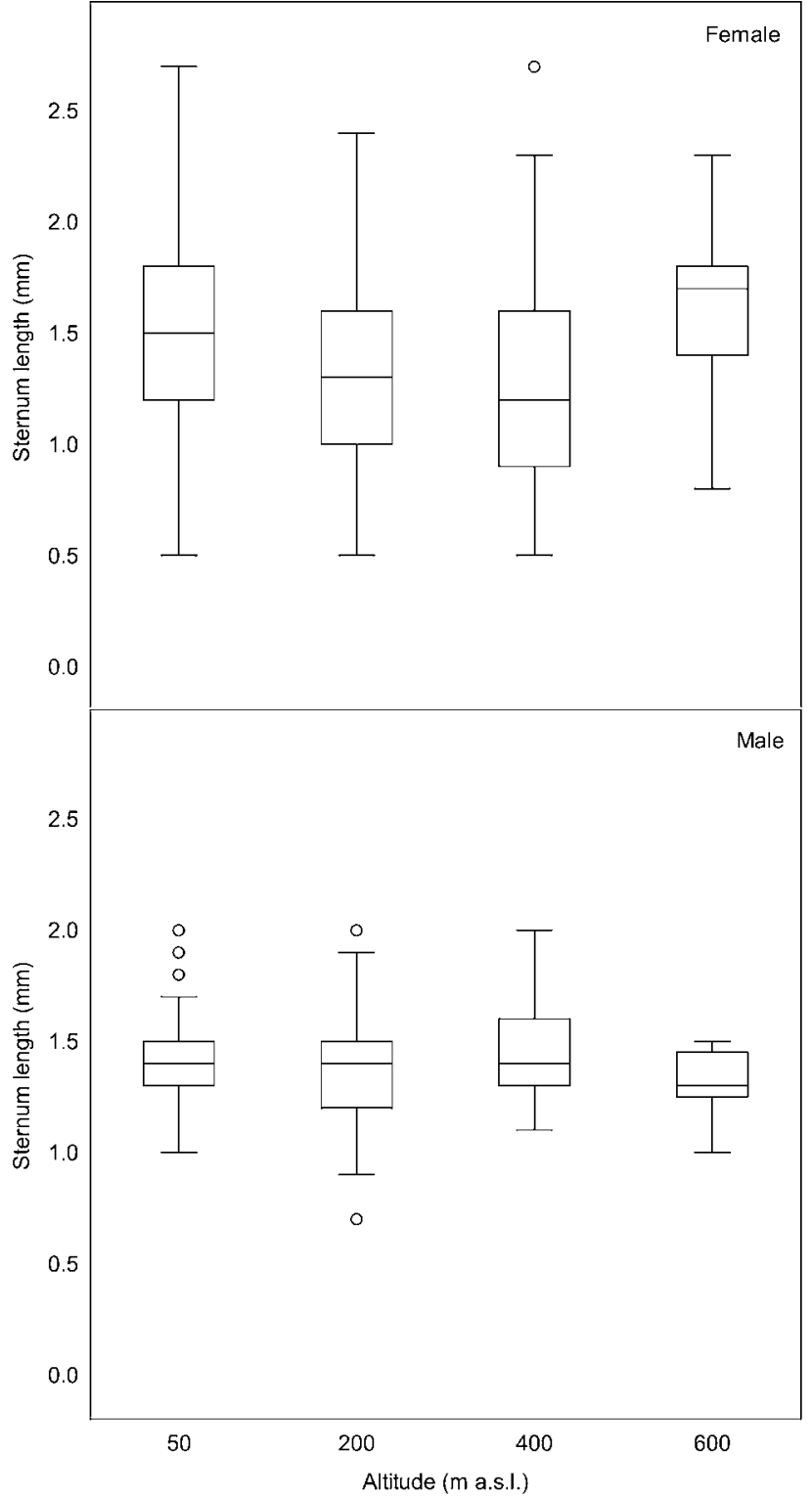

Fig. 6. Boxplot showing median (25-75\%), non-outlier range (whiskers), outliers (o) of M. kerguelenensis sternum width across the sampled altitudinal gradient in a. females and b. males.

females proportionally (i.e. $87 \%$ of the population) (Fig. 5). At high altitude sites large males are largely absent (see Fig. 6), indicating that it is this group skewing the sex ratio.

\section{Discussion}

Fellfield spider assemblages on Marion Island almost entirely comprised M. kerguelenensis. At low altitude sites and in the summer (Fig. 3) the densities of M. kerguelenensis were approximately comparable to spider densities found in temperate systems (typically from 2-20 individuals $\mathrm{m}^{-2}$ ) (Vargas 2000), so partly validating our sampling approach. 
However, at higher elevations and in the winter, densities of $M$. kerguelenensis decline sharply. This finding is consistent with other sub-Antarctic systems where decreasing density of a variety of invertebrate taxa (including mites, springtails, aphids and slugs) has been found across a similar altitudinal range (e.g. Davies \& Melbourne 1999, Barendse \& Chown 2001, Lee et al. 2009, Abraham et al. 2011).

A variety of non-exclusive mechanisms may act in synergy to explain the lower population densities at high altitudes. In an environment where temperatures are typically low and may fall below $0^{\circ} \mathrm{C}$ at any time of the year (le Roux \& McGeoch 2008b), thermal constraints provide an obvious starting point. For example, the upper elevation range margins of the introduced slug, Deroceras panormitanum (Lessona and Pollonera), are a function of the inability of this species to survive temperatures below an absolute limit of $-6.4^{\circ} \mathrm{C}$, which is exceeded at $200 \mathrm{~m}$ a.s.l. (Lee et al. 2009). For M. kerguelenensis, critical thermal minima lie between -6 and $-7^{\circ} \mathrm{C}$ (Jumbam et al. 2008) and so thermal constraints may also pose some limitation on the upper altitudinal limit of this species. However, these low temperature events are typically short-lived and, unlike the relatively slow moving slug, M. kerguelenensis is highly mobile and so it may avoid freeze mortality by temporarily moving to more favourable microsites. For example, in the fellfield habitat where M. kerguelenensis is most abundant, the dominant cushion plant, Azorella selago, has a significant impact on the fine scale soil thermal regime by increasing mean, minimum and maximum soil temperatures on the western side of cushions (Haussmann et al. 2009). Thermal constraints may also influence courtship and copulatory behaviours with longer copulation periods and greater probability of egg sack production at warmer temperatures in some spider species (Chen et al. 2010). Temperatures may also affect locomotor performance with lower temperatures resulting in increased predation by house mice (Mus musculus L.), decreased hunting areas, decreased encounter rate with prey and less efficient capture prey (Kruse et al. 2008) that would ultimately slow growth at both individual and population levels.

A complementary explanation for declining $M$. kerguelenensis density at high altitudes is resource limitation. Although, broadly speaking, fellfield habitat occurs up to altitudes of $600 \mathrm{~m}$ a.s.l., at higher elevations vegetation becomes increasingly sparse (Smith et al. 2001) and associated invertebrates such as springtails become less abundant (Gabriel et al. 2001). Lower prey densities would mean that individual spiders would need to utilize a greater area to catch sufficient food and so overall spider densities would be lower. The low resource hypothesis may also help to explain the highly female-biased sex ratios at higher altitudes as it may result in conditions whereby cannibalism becomes prevalent. Cannibalism occurs in a wide range of generalist predators and has been extensively studied in spiders, where sexual cannibalism appears to be most common and has received the greatest amount of attention (see Wise 2006 for review). Sexual cannibalism almost exclusively involves females killing and eating males and may occur pre- or post-copulation. Pre-copulatory cannibalism occurs when females choose to prey upon male spiders, preferring to eat them and increase their own and their young's likelihood of survival rather than using that individual for a mate (Wise 2006). In this case it is commonly smaller males who are predated as the risk of injury or death from attacking an individual of approximately equal body size is high. Post-copulatory cannibalism is commonly explained as male investment in young in a low resource environment and may be voluntary or involuntary (Wise 2006). Further experimentation is required to determine if cannibalism is prevalent on Marion Island, if it is pre- or post-copulatory, or if the skewed sex ratio is a sampling artefact.

The high levels of intra-sexual body size variation in M. kerguelenensis are consistent with the degree of variability found in some other invertebrate species on the island such as Pringleophaga marioni Viette and Ectemorhinus spp. (Mercer et al. 2001). Large-bodied individuals of these species are the preferred prey of the introduced house mouse (Smith et al. 2002). Removal of large individuals in this way is thought to be driving a reduction in adult body size (Chown \& Smith 1993). A combination of a general trend in decreasing body size, heterogeneous levels of mouse predation resulting in the survival of some larger individuals, and effects of altitude and season (see Table II) may explain the large range in body size seen for $M$. kerguelenensis, which form a significant component of the diet of mice (Smith et al. 2002). Despite these high levels of variation within sites, little directional variation in size was found over the altitudinal gradient (although altitude is a significant factor in the model the effect size is negligible - see Table II). This finding is inconsistent with either Bergmann's rule (as applied at the intraspecific level) or the converse Bergmann size trend (see review in Blanckenhorn \& Demont 2004). The latter is expected for the largely aseasonal environment at Marion Island (Chown \& Klok 2003), but is not supported. Why this should be the case probably has to do with interactions between the largely aseasonal environment, and altitudinal variation in resource availability, sex ratio and predation pressure (see Warren et al. 2006 for an introduction to these interactions). Comprehensive sampling of the species and its food resources would be required to address the mechanistic basis of the finding. Such trophic complexity and its implications for populations in the region have not been well studied, and the current findings provide additional motivation for why such work is required (see also Hogg et al. 2006).

In conclusion, although $M$. kerguelenensis densities on Marion Island decline with increasing altitude, and sex ratios become increasingly skewed, populations are maintained up to elevations of at least $600 \mathrm{~m}$ a.s.l. forming an important component of the mid-to-high altitude food web. The probable complexity of this food web, as a consequence of 
varying densities and invariant size with altitude, and the implications thereof for the demographics and life histories of species in the food web, have probably been previously underestimated. Thus, investigations of trophic interactions would provide much insight into ecological dynamics on this island and others in the region that are home to indigenous spiders, and may prove especially important for elucidating the impacts of biological invasions as climates continue to change (see Frenot et al. 2005, Hogg et al. 2006, Chown et al. 2007). If sub-Antarctic spider populations respond in a similar manner to Arctic populations, information on body size variation may also be important to track variation in sexual size dimorphism in response to climate change (Høye et al. 2009).

\section{Acknowledgements}

We thank Richard Mercer for helping with logistics and advice and Kamva Qwede for data collection. Fieldwork by KQ and MJS was supported by a USAID grant to SLC and by the South African Department of Environmental Affairs and Tourism. The South African National Antarctic Programme provided logistic support. Anne Treasure, Toke Høye and an anonymous referee provided helpful comments on a draft version of the manuscript and Peter le Roux provided statistical advice.

\section{Supplementary materials}

For supplementary material for this article, please visit http://dx.doi.org/10.1017/S0954102011000629.

\section{References}

Abraham, S., Somers, M.J. \& Chown, S.L. 2011. Seasonal, altitudinal and host-related variation in the abundance of aphids (Insecta, Hemiptera) on sub-Antarctic Marion Island. Polar Biology, 34, 513-520.

Andrewartha, H.G. \& Birch, L.C. 1954. The distribution and abundance of animals. Chicago: University of Chicago Press, $793 \mathrm{pp}$.

Arnold, R.J. \& Convey, P. 1998. The life history of the diving beetle, Lancetes angusticollis (Curtis) (Coleoptera: Dytiscidae), on subAntarctic South Georgia. Polar Biology, 20, 153-160.

Barendse, J. \& Chown, S.L. 2001. Abundance and seasonality of midaltitude fellfield arthropods from Marion Island. Polar Biology, 24, 73-82.

Blanckenhorn, W.U. \& Demont, M. 2004. Bergmann and converse Bergmann latitudinal clines in arthropods: two ends of a continuum? Integrative and Comparative Biology, 44, 413-424.

BuRger, A.E. 1978. Terrestrial invertebrates: a food resource for birds at Marion Island. South African Journal of Antarctic Research, 8, 87-99.

Chen, Z.Q., Jiao, X.G., Wu, J., Chen, J. \& Liu, F.X. 2010. Effects of copulation temperature on female reproductive output and longevity in the wolf spider Pardosa astrigera (Araneae: Lycosidae). Journal of Thermal Biology, 35, 125-128.

Chown, S.L. 1992. A preliminary analysis of weevil assemblages in the sub-Antarctic: local and regional patterns. Journal of Biogeography, 19, 87-98.

Chown, S.L. \& BLock, W. 1997. Comparative nutritional ecology of grassfeeding in a sub-Antarctic beetle: the impact of introduced species on Hydromedion sparsutum from South Georgia. Oecologia, 111, 216-224.
Chown, S.L. \& Convey, P. 2007. Spatial and temporal variability across life's hierarchies in the terrestrial Antarctic. Philosophical Transactions of the Royal Society of London, B362, 2307-2331.

Chown, S.L. \& Froneman, P.W., eds. 2008. The Prince Edward Islands: land-sea interactions in a changing ecosystem. Stellenbosch: Sun Press, $450 \mathrm{pp}$.

Chown, S.L. \& Gaston, K.J. 2010. Body size variation in insects: a macroecological perspective. Biological Reviews, 85, 139-169.

Chown, S.L. \& KLoK, C.J. 2003. Altitudinal body size clines: latitudinal effects associated with changing seasonality. Ecography, 26, 445-455.

Chown, S.L. \& Sмith, V.R. 1993. Climate change and the short-term impact of feral house mice at the sub-Antarctic Prince Edward Islands. Oecologia, 96, 508-516.

Chown, S.L., Slabber, S., McGeoch, M.A., Janion, C. \& Leinaas, H.P. 2007. Phenotypic plasticity mediates climate change responses among invasive and indigenous arthropods. Proceedings of the Royal Society of London, B274, 2531-2537.

Convey, P., Chown, S.L., Wasley, J. \& Bergstrom, D.M. 2006. Life history traits. In Bergstrom, D.M., Convey, P. \& Huiskes, A.H.L., eds. Trends in Antarctic terrestrial and limnetic ecosystems. Dordrecht: Springer, 101-127.

Cohen, J.E., Jonsson, T. \& CARpenter, S.R. 2003. Ecological community description using the food web, species abundance, and body size. Proceedings of the National Academy of Sciences of the United States of America, 100, 1781-1786.

Cohen, J.E., Jonsson, T., Müller, C.B., Godfray, H.C.J. \& Savage, V.M. 2005. Body sizes of hosts and parasitoids in individual feeding relationships. Proceedings of the National Academy of Sciences of the United States of America, 102, 684-689.

Davies, K.F. \& Melbourne, B.A. 1999. Statistical models of invertebrate distribution on Macquarie Island: a tool to assess climate change and local human impacts. Polar Biology, 21, 240-250.

Davies, L. 1972. Two Amblystogenium species (Col. Carabidae) co-existing on the subantarctic Possession Island, Crozet Islands. Entomologica Scandinavica, 3, 275-286.

Ernsting, G., Brandjes, G.J., Block, W. \& Isaaks, J.A. 1999. Life-history consequences of predation for a subantarctic beetle: evaluating the contribution of direct and indirect effects. Journal of Animal Ecology, 68, 741-752.

Frenot, Y., Chown, S.L., Whinam, J., Selkirk, P.M., Convey, P., Skotnicki, M. \& Bergstrom, D.M. 2005. Biological invasions in the Antarctic: extent, impacts and implications. Biological Reviews, 80, 45-72.

Gabriel, A.G.A., Chown, S.L., Barendse, J., Marshall, D.J., Mercer, R.D., Pugh, P.J.A. \& SмITH, V.R. 2001. Biological invasions of Southern Ocean islands: the Collembola of Marion Island as a test of generalities. Ecography, 24, 421-430.

Hagstrum, D.W. 1971. Carapace width as a tool for evaluating the rate of development of spiders in the laboratory and field. Annals of the Entomological Society of America, 64, 757-760.

Haussmann, N.S., Boelhouwers, J.C. \& Mcgeoch, M.A. 2009. Fine scale variability in soil frost dynamics surrounding cushions of the dominant vascular plant species (Azorella selago) on sub-Antarctic Marion Island. Geografiska Annaler, 91A, 257-286.

Hogg, I.D., Cary, S.C., Convey, P., Newhham, K.K., O’Donnell, A.G., Adams, B.J., Aislabie, J., Frati, F., Stevens, M.I. \& Wall, D.H. 2006. Biotic interactions in Antarctic terrestrial ecosystems: are they a factor? Soil Biology and Biochemistry, 38, 3035-3040.

Høye, T.T., Hammel, J.U., Fuchs, T. \& Toft, S. 2009. Climate change and sexual size dimorphism in an Arctic spider. Biology Letters, 5, 542-544.

Johnson, J.B. \& Omland, K.S. 2004. Model selection in ecology and evolution. Trends in Ecology and Evolution, 19, 101-108.

Jumbam, K., Terblanche, J.S., Deere, J.A., Somers, M. \& Chown, S.L. 2008. Critical thermal limits and their responses to acclimation in two sub-Antarctic spiders: Myro kerguelenensis and Prinerigone vagans. Polar Biology, 31, 215-220. 
Khoza, T.T., Dippenaar, S.M. \& Dippenaar-Schoeman, A.S. 2005. The biodiversity and species composition of the spider community of Marion Island, a recent survey (Arachnida: Araneae). Koedoe, 48, 103-107.

Kruse, P.D., Toft, S. \& Sunderland, K.D. 2008. Temperature and prey capture: opposite relationships in two predator taxa. Ecological Entomology, 33, 305-312.

Lawrence, K.L. \& Wise, D.H. 2000. Spider predation on forest-floor Collembola and evidence for indirect effects on decomposition. Pedobiologia, 44, 33-39.

Lawrence, R.F. 1971. Araneida. In VAN Zinderen BakKer, E.M., Winterbottom, J.M. \& Dyer, R.A., eds. Marion and Prince Edward Island: report on the South African biological and geological expedition 1965-1966. Cape Town: A.A. Balkema, 301-313.

Lee, J.E., Janion, C., Marais, E., van Vuuren, B.J. \& Chown, S.L. 2009. Physiological tolerances account for range limits and abundance structure in an invasive slug. Proceedings of the Royal Society of London, B276, 1459-1468.

Lee, J.E., Slabber, S., van Vuuren, B.J., van Noort, S. \& Chown, S.L. 2007. Colonisation of sub-Antarctic Marion Island by a non-indigenous aphid parasitoid Aphidius matricariae (Hymenoptera, Braconidae). Polar Biology, 30, 1195-1201.

Legendre, P. \& Legendre, L. 1998. Numerical ecology. Amsterdam: Elsevier, $853 \mathrm{pp}$.

Le Roux, P.C. \& McGeoch, M.A. 2008a. Spatial variation in plant interactions across a severity gradient in the sub-Antarctic. Oecologia, 155, 831-844.

Le Roux, P.C. \& McGeoch, M.A. 2008b. Changes in climate extremes, variability and signature on sub-Antarctic Marion Island. Climatic Change, 86, 309-329.

Mercer, R.D., Gabriel, A.G.A., Barendse, J., Marshall, D.J. \& Chown, S.L. 2001. Invertebrate body sizes from Marion Island. Antarctic Science, 13, 135-143.
Peters, R.H. 1983. The ecological implications of body size. Cambridge: Cambridge University Press, 344 pp.

Pugh, P.J.A. 2004. Biogeography of spiders (Araneae: Arachnida) on the islands of the Southern Ocean. Journal of Natural History, 38, 1461-1487.

Quinn, G.P. \& Keough, M.J. 2002. Experimental design and data analysis for biologists. Cambridge: Cambridge University Press, $537 \mathrm{pp.}$

R Development Core Team. 2010. $R$ : a language and environment for statistical computing. Vienna: R Foundation for Statistical Computing, http://www.R-project.org.

SмITH, V.R. 2008. Energy flow and nutrient cycling in the Marion island terrestrial system: 30 years on. Polar Record, 44, 211-226.

Smith, V.R., Avenant, N. \& Chown, S.L. 2002. The diet and impact of house mice of a sub-Antarctic island. Polar Biology, 25, 703-715.

Smith, V.R., Steenkamp, M. \& Gremmen, N.J.M. 2001. Terrestrial habitats on sub-Antarctic Marion Island: their vegetation, edaphic attributes, distribution and response to climate change. South African Journal of Botany, 67, 641-654.

VARGas, A.J. 2000. Effects of fertilizer addition and debris removal on leaf-litter spider communities at two elevations. Journal of Arachnology, 28, 79-89.

Warren, M., McGeoch, M.A., Nicolson, S.W. \& Chown, S.L. 2006. Body size patterns in Drosophila inhabiting a mesocosm: interactive effects of spatial variation in temperature and abundance. Oecologia, 149, 245-255.

Wise, D.H. 2006. Cannibalism, food limitation, intraspecific competition and the regulation of spider populations. Annual Review of Entomology, 51, 441-465.

Ysnel, F. \& Ledoux, J.-C. 1988. Donnees sur le cycle biologique de quelques araignees des terres Australes Francaises (Kerguelen, Crozet). Bulletin de la Société scientifique de Bretagne, 59, 209-221. 